\title{
PENGARUH LIMBAH PLASTIK LOW DENSITY POLYETHYLENE TERHADAP KARAKTERISTIK DASAR ASPAL
}

\author{
Birahmatika Afriyanto \\ Jurusan Teknik Sipil \\ Universitas Jenderal Soedirman \\ Jln. Mayjend Sungkono Km 5 \\ Blater Purbalingga 53371 \\ birahmatikafriyanto@gmail.com
}

\author{
Eva Wahyu Indriyati \\ Jurusan Teknik Sipil \\ Universitas Jenderal Soedirman \\ Jln. Mayjend Sungkono Km 5 \\ Blater Purbalingga 53371 \\ indriyati.eva@gmail.com
}

\author{
Probo Hardini \\ Jurusan Teknik Sipil \\ Universitas Jenderal Soedirman \\ Jln. Mayjend Sungkono Km 5 \\ Blater Purbalingga 53371 \\ probo.hardini@unsoed.ac.id
}

\begin{abstract}
One way to reduce damage of the pavement structure is to improve the quality of asphalt used. In an effort to improve the quality of the asphalt, additives are added, such as polymers. This study aims to determine the basic characteristics of Low Density Polyethylene Plastic modified asphalt, which includes penetration, softening point, flash and fire point, specific gravity, ductility, viscosity. In addition, it will be determined the maximum content of Low Density Polyethylene Plastic which produces modified asphalt that meets the standards of the Directorate General of Highways. The results of this study show that modified asphalt with Low Density Polyethylene Plastic can increase the asphalt softening point and reduce penetration value, flash and fire point, specific gravity, ductility, and viscosity of asphalt. The maximum LDPE Plastic content that can produce modified asphalt that meets specifications of the Directorate General of Highways is $5 \%$.
\end{abstract}

Keywords: plastic, asphalt quality, additives, basic characteristics of asphalt, modified asphalt

\begin{abstract}
Abstrak
Salah satu cara untuk mengurangi kerusakan struktur perkerasan jalan adalah dengan meningkatkan mutu aspal yang digunakan. Dalam upaya peningkatan mutu aspal dilakukan penambahan bahan aditif, seperti polimer. Penelitian ini bertujuan untuk mengetahui karakteristik dasar aspal modifikasi plastik Low Density Polyethylene, yang meliputi penetrasi, titik lembek, titik nyala dan titik bakar, berat jenis, daktilitas, viskositas. Selain itu, akan ditentukan kadar maksimal plastik Low Density Polyethylene maksimal yang menghasilkan aspal modifikasi yang memenuhi standar Bina Marga. Hasil pengujian menunjukkan bahwa aspal modifikasi dengan plastik Low Density Polyethylene dapat meningkatkan titik lembek aspal serta menurunkan nilai penetrasi, titik nyala dan titik bakar, berat jenis, daktilitas, dan viskositas aspal. Kadar plastik LDPE maksimal yang dapat menghasilkan aspal modifikasi yang memenuhi persyaratan Bina Marga adalah $5 \%$.
\end{abstract}

Kata-kata kunci: plastik, mutu aspal, bahan aditif, karakteristik dasar aspal, aspal modifikasi

\section{PENDAHULUAN}

Beban lalu lintas yang berat merupakan salah satu faktor penyebab kerusakan jalan. Salah satu cara mengurangi kerusakan jalan adalah dengan meningkatkan mutu aspal. Peningkatan mutu aspal ini dapat dilakukan dengan menambah bahan aditif, seperti polimer, plastik, arang, atau aspal modifikasi (Rahmawati, 2015). Campuran aspal dengan bahan tambah polimer plastik mampu meningkatkan kekakuan aspal, sehingga aspal tahan terhadap temperatur yang tinggi karena plastik memiliki titik lembek yang tinggi.

Menurut Rahmawati dan Rizana (2013), pada tahun 2010 konsumsi plastik di dunia mencapai angka 255 miliar kilogram dan mengalami peningkatan sebesar $24,4 \%$ 
selama kurun waktu 4 tahun. Menurut Sunarya (2016), terkait sampah plastik, Indonesia menduduki peringkat kedua penghasil sampah domestik, yaitu sebesar 5,4 juta ton per tahun. Limbah plastik ini merupakan masalah limbah terbesar di dunia karena bahan plastik sulit diuraikan.

Pada penelitian ini digunakan limbah kantong plastik sebagai bahan aditif campuran aspal. Hal ini diharapkan dapat menjadi salah satu solusi untuk mengurangi limbah plastik. Penelitian sebelumnya sudah dilakukan terkait dengan penggunaan limbah plastik, yang salah satunya dilakukan oleh Wantoro et al., (2013), yang melakukan penelitian pemanfaatan limbah plastik Low Density Polyethylene (LDPE) untuk bahan campuran aspal dengan variasi kadar plastik $0 \%, 2 \%, 4 \%$, dan 6\%. Penelitian tersebut tidak menentukan jumlah kadar plastik maksimal yang dapat digunakan untuk campuran aspal, sehingga penelitian ini akan menyempurnakan penelitian yang telah dilakukan tersebut. Penelitian ini menggunakan varisi kadar plastik LDPE sebesar 0\%, 1\%, 2\%, 3\%, 4\%, 5\%, $6 \%, 7 \%, 8 \%, 9 \%, 10 \%, 20 \%, 30 \%, 40 \%$, dan 50\% dengan tujuan agar lebih tepat dalam mendapatkan kadar plastik maksimal untuk campuran aspal sesuai persyaratan Bina Marga.

Pencampuran aspal keras dengan bahan tambah disebut aspal modifikasi. Aspal modifikasi telah dikembangkan di berbagai negara di dunia termasuk di Indonesia. Aspal modifikasi memiliki sifat mekanik yang lebih baik dibandingkan dengan aspal dasarnya. Menurut Syahputri (2014), penggunaan aspal modifikasi terus mengalami peningkatan dalam beberapa dekade terakhir. Polimer merupakan bahan yang sering digunakan saat ini sebagai bahan tambah campuran aspal. Penggunaan bahan polimer yang semakin meningkat tidak hanya mempertimbangkan faktor ekonomi, tetapi juga bertujuan untuk meningkatkan kualitas aspal yang lebih baik dan tahan lama.

Modifikasi aspal dengan bahan tambah polimer dapat menjadi inovasi baru dalam perkerasan lentur. Akan tetapi, untuk menghasilkan aspal modifikasi yang layak digunakan untuk perkerasan lentur harus memenuhi persyaratan yang telah ditetapkan oleh Bina Marga. Persyaratan tersebut dapat dilihat di Tabel 1.

Tabel 1 Persyaratan Aspal Modifikasi (Bina Marga, 2010)

\begin{tabular}{|c|c|c|c|c|c|}
\hline \multirow{2}{*}{ No. } & \multirow{2}{*}{ Jenis Pengujian } & \multirow{2}{*}{ Metode Pengujian } & \multicolumn{2}{|c|}{ Persyaratan } & \multirow{2}{*}{ Satuan } \\
\hline & & & Min & Maks & \\
\hline 1. & Penetrasi & SNI-06-2456-1991 & 40 & - & $0,1 \mathrm{~mm}$ \\
\hline 2. & Titik nyala & SNI-06-2433-1991 & 232 & - & ${ }^{\circ} \mathrm{C}$ \\
\hline 3. & Titik lembek & SNI-06-2434-1991 & 54 & - & ${ }^{\circ} \mathrm{C}$ \\
\hline 4. & Daktilitas & SNI-06-2432-1991 & 100 & - & $\mathrm{cm}$ \\
\hline 5. & Berat jenis & SNI-06-2441-1991 & 1 & - & $\mathrm{gr} / \mathrm{cm}^{3}$ \\
\hline 6. & Viskositas & SNI-06-6441-2000 & - & 3000 & $\mathrm{cSt}$ \\
\hline
\end{tabular}

Terdapat 3 metode pencampuran aspal dengan plastik untuk menghasilkan aspal modifikasi yang homogen dan tidak menggumpal (Sistra et al., 2016). Metode-metode tersebut adalah Campuran Aspal Dingin-Plastik Dingin, Campuran Aspal Panas-Plastik Dingin, dan Campuran Aspal Panas-Plastik Panas. 
Pada Metode Campuran Aspal Dingin-Plastik Dingin, pencampuran dilakukan dengan memasukkan aspal dan plastik pada wadah yang sama, kemudian dilakukan pemanasan dan pengadukan. Proses ini dilakukan hingga aspal modifikasi menjadi homogen. Temperatur pencampuran saat aspal modifikasi menjadi homogen dicatat.

Pada Metode Campuran Aspal Panas-Plastik Dingin, pencampuran dilakukan dengan cara aspal dipanaskan terlebih dahulu hingga cair, kemudian ditambahkan plastik. Selanjutnya dilakukan pengadukan selama pencampuran hingga menghasilkan aspal modifikasi yang homogen. Temperatur pencampuran saat diperoleh aspal modifikasi yang homogen dicatat.

Pada Metode Campuran Aspal Panas-Plastik Panas, aspal dan plastik dipanaskan pada wadah yang berbeda. Setelah keduanya mencair, aspal dituang ke dalam wadah plastik yang telah mencair. Kemudian dilakukan pengadukan selama pencampuran hingga aspal modifikasi menjadi homogen dan temperatur pencampuran saat diperoleh campuran yang homogen dicatat.

Pencampuran dilakukan dengan menggunakan api yang sedang dan diaduk sampai campuran tidak menggumpal. Untuk mengetahui campuran telah homogen atau tidak dilakukan dengan cara visual, yaitu dengan cara melihat apakah campuran aspal dan plastik tercampur dengan sempurna dan tidak terjadi penggumpalan plastik dalam campuran aspal.

Plastik Low Density Polyethylene (LDPE) adalah jenis plastik termoplastik yang terbuat dari minyak bumi. Plastik LDPE ini memiliki densitas rendah, yaitu antara $(0,910-0,940) \mathrm{gr} / \mathrm{cm}^{3}$, tidak reaktif pada temperatur kamar, kecuali oleh oksidator kuat dan beberapa jenis pelarut yang dapat menyebabkan kerusakan (Wantoro et al., 2013). Menurut Plastik LDPE memiliki titik leleh sebesar $(105-115)^{\circ} \mathrm{C}$ dan tidak mudah bereaksi dengan bahan kimia lain.

Penelitian ini dilaksanakan di Laboratorium Transportasi, Fakultas Teknik, Universitas Jenderal Soedirman, Purbalingga. Pembuatan benda uji dilakukan dengan menggunakan metode pencampuran aspal panas dan plastik dingin. Akan tetapi, plastik LDPE dingin diproses terlebih dahulu dengan cara dibakar hingga meleleh sempurna. Kemudian hasil lelehan plastik LDPE didiamkan sekitar 30 menit hingga plastik tersebut mengeras. Plastik hasil pembakaran yang telah didinginkan kemudian ditimbang sesuai porsi kadar pengujian untuk dicampurkan ke dalam aspal panas. Kemudian aspal modifikasi plastik LDPE tersebut dituang ke dalam media benda uji untuk masing-masing pengujian.

Setelah pengujian karakteristik dasar aspal dilaksanakan, tahap selanjutnya adalah melakukan analisis data pengujian dengan cara membandingkan pengaruh penambahan kadar plastik LDPE pada aspal modifikasi terhadap persyaratan aspal modifikasi Spesifikasi Umum Bina Marga 2010. Kemudian ditentukan rentang kadar aspal maksimum aspal modifikasi plastik LDPE dengan membuat tabulasi hasil perbandingan tersebut, dengan cara dipilih kadar penambahan plastik yang memenuhi syarat semua pengujian menurut persyaratan Bina Marga 2010. Dari proses ini diperoleh jumlah penambahan kadar plastik 
maksimum yang layak untuk aspal modifikasi, yang memenuhi persyaratan yang telah ditentukan.

\section{HASIL DAN PEMBAHASAN}

\section{Pengujian Penetrasi}

Pengujian penetrasi bertujuan untuk menentukan nilai penetrasi aspal. Persyaratan nilai penetrasi untuk aspal modifikasi dengan polimer yang ditetapkan oleh Bina Marga 2010 adalah minimal 40. Hasil pengujian penetrasi aspal modifikasi dengan plastik LDPE dapat dilihat pada Tabel 2.

Tabel 2 Hasil Pegujian Penetrasi Aspal Modifikasi

\begin{tabular}{ccccc}
\hline No. & Kadar & Sampel 1 & Sampel 2 & Rata-Rata \\
\hline 1. & $0 \%$ & 64,6 & 63,0 & 63,80 \\
2. & $1 \%$ & 64,4 & 59,2 & 61,80 \\
3. & $2 \%$ & 52,8 & 64,2 & 58,50 \\
4. & $3 \%$ & 52,4 & 63,0 & 57,70 \\
5. & $4 \%$ & 42,5 & 49,0 & 45,75 \\
6. & $5 \%$ & 39,0 & 43,6 & 41,30 \\
7. & $6 \%$ & 40,0 & 37,2 & 38,60 \\
8. & $7 \%$ & 37,6 & 35,0 & 36,30 \\
9. & $8 \%$ & 23,6 & 22,2 & 22,90 \\
\hline
\end{tabular}

Hasil pengujian tersebut memperlihatkan bahwa aspal modifikasi plastik sudah memenuhi persyaratan Bina Marga untuk pengujian penetrasi, dengan kadar plastik sebesar $1 \%$ sampai 5\%. Pada kadar plastik sebesar 6\% sampai $8 \%$ diperoleh rata-rata nilai penetrasi kurang dari nilai penetrasi yang telah ditetapkan oleh Bina Marga, yaitu minimal 40.

\section{Pengujian Berat Jenis}

Pengujian ini bertujuan untuk mengetahui berat jenis aspal modifikasi plastik LDPE. Bina Marga telah menetapkan persyaratan nilai berat jenis untuk aspal modifikasi dengan plastik, yaitu minimum 1,0. Hasil pengujian berat jenis aspal modifikasi dengan plastik LDPE dapat dilihat pada Tabel 3. Dari tabel hasil pengujian tersebut terlihat bahwa semakin besar penambahan kadar plastik LDPE, semakin kecil berat jenis aspal modifikasi. Hasil yang diperoleh dalam pengujian berat jenis aspal modifikasi adalah bahwa kadar plastik 0\% sampai $8 \%$ memberikan aspal modifikasi yang memenuhi persyaratan Bina Marga.

\section{Pengujian Daktilitas}

Pengujian daktilitas bertujuan untuk mengetahui tingkat plastisitas aspal modifikasi dengan plastik LDPE. Persyaratan untuk pengujian daktilitas menurut Spesifikasi Umum Bina Marga 2010 adalah paling sedikit $100 \mathrm{~cm}$. Hasil pengujian daktilitas aspal modifikasi dengan plastik LDPE dapat dilihat pada Tabel 4. 
Tabel 3 Hasil Pengujian Berat Jenis Aspal Modifikasi

\begin{tabular}{ccccc}
\hline No. & Kadar & $\begin{array}{c}\text { Berat Jenis } \\
\text { Sampel 1 }\end{array}$ & $\begin{array}{c}\text { Berat Jenis } \\
\text { Sampel 2 }\end{array}$ & $\begin{array}{c}\text { Berat Jenis } \\
\text { Rata-rata }\end{array}$ \\
\hline 1. & $0 \%$ & 1,03279 & 1,02674 & 1,02976 \\
2. & $1 \%$ & 1,02618 & 1,02646 & 1,02632 \\
3. & $2 \%$ & 1,02564 & 1,02525 & 1,02545 \\
4. & $3 \%$ & 1,02513 & 1,02151 & 1,02332 \\
5. & $4 \%$ & 1,02020 & 1,02439 & 1,02230 \\
6. & $5 \%$ & 1,02041 & 1,02116 & 1,02079 \\
7. & $6 \%$ & 1,01622 & 1,02041 & 1,01831 \\
8. & $7 \%$ & 1,01951 & 1,01932 & 1,01942 \\
\hline 9. & $8 \%$ & 1,02094 & 1,01531 & 1,01812 \\
\hline
\end{tabular}

Tabel 4 Hasil Pengujian Daktilitas Aspal Modifikasi

\begin{tabular}{ccccc}
\hline No. & Kadar & $\begin{array}{c}\text { Sampel 1 } \\
(\mathrm{cm})\end{array}$ & $\begin{array}{c}\text { Sampel 2 } \\
(\mathrm{cm})\end{array}$ & $\begin{array}{c}\text { Rata-Rata } \\
(\mathrm{cm})\end{array}$ \\
\hline 1. & $0 \%$ & 110,5 & 125 & 117,75 \\
2. & $1 \%$ & 125 & 105,4 & 115,2 \\
3. & $2 \%$ & 102,6 & 120,5 & 111,55 \\
4. & $3 \%$ & 107,3 & 112,6 & 109,95 \\
5. & $4 \%$ & 106,9 & 110,3 & 108,6 \\
6. & $5 \%$ & 103,8 & 108,2 & 106 \\
7. & $6 \%$ & 100,7 & 105,4 & 103,05 \\
8. & $7 \%$ & 84,3 & 101,6 & 92,95 \\
9. & $8 \%$ & 85,2 & 93,3 & 89,25 \\
\hline
\end{tabular}

Semakin besar penambahan kadar plastik LDPE, semakin kecil tingkat keplastisan aspal modifikasi. Hal tersebut karena penambahan plastik pada campuran aspal akan membuat aspal menjadi semakin getas dan keras, sehingga menurunkan keplastisan aspal tersebut. Terlihat bahwa kadar plastik yang menghasilkan aspal modifikasi yang memenuhi persyaratan daktilitas Bina Marga adalah kadar antara 0\% sampai 6\%. Kadar plastik 7\% dan $8 \%$ menghasilkan aspal modifikasi yang tidak memenuhi spesifikasi, karena memiliki keplastisan kurang dari 100.

\section{Pengujian Titik Lembek}

Titik lembek merupakan pengujian untuk menentukan temperatur ketika aspal mencapai derajat kelembekannya. Persyaratan pengujian titik lembek aspal modifikasi yang telah ditentukan oleh Bina Marga adalah paling sedikit $54^{\circ} \mathrm{C}$. Hasil pengujian titik lembek aspal modifikasi plastik LDPE dapat dilihat pada Tabel 5. Berdasarkan hasil pengujian tersebut, penambahan kadar plastik LDPE meningkatkan titik lembek aspal. Hal tersebut terjadi karena sifat plastik LDPE apabila dicampur dengan aspal meningkatkan titik lembek aspal. Hasil pengujian tersebut menunjukkan bahwa kadar plastik $1 \%$ sampai 8\% memenuhi menghasilkan aspal modifikasi yang memenuhi persyaratan.

\section{Pengujian Titik Nyala dan Titik Bakar}

Pengujian ini bertujuan untuk mengetahui temperatur maksimum pemanasan aspal modifikasi yang masih dalam batas aman, sehingga karakteristik aspal modifikasi tersebut 
tidak berubah karena pemanasan. Persyaratan titik nyala aspal modifikasi yang telah ditetapkan oleh Bina Marga adalah paling sedikit $232^{\circ} \mathrm{C}$. Hasil pengujian titik nyala dan titik bakar aspal modifikasi dengan plastik LDPE dapat dilihat pada Tabel 6.

Tabel 5 Hasil Pengujian Titik Lembek Aspal Modifikasi

\begin{tabular}{cccrr}
\hline No. & Kadar & $\begin{array}{c}\text { Sampel 1 } \\
\left({ }^{\circ} \mathrm{C}\right)\end{array}$ & $\begin{array}{c}\text { Sampel 2 } \\
\left({ }^{\circ} \mathrm{C}\right)\end{array}$ & $\begin{array}{c}\text { Rata-Rata } \\
\left({ }^{\circ} \mathrm{C}\right)\end{array}$ \\
\hline 1. & $0 \%$ & 51,4 & 52,2 & 51,80 \\
2. & $1 \%$ & 54,3 & 55,6 & 54,95 \\
3. & $2 \%$ & 59,9 & 61,3 & 60,60 \\
4. & $3 \%$ & 64,1 & 70,5 & 67,30 \\
5. & $4 \%$ & 68,6 & 74,2 & 71,40 \\
6. & $5 \%$ & 80,1 & 81,2 & 80,65 \\
7. & $6 \%$ & 82,1 & 85,6 & 83,85 \\
8. & $7 \%$ & 84,3 & 95,6 & 89,95 \\
9. & $8 \%$ & 89,4 & 101,1 & 95,25 \\
\hline
\end{tabular}

Tabel 6 Hasil Pengujian Titik Nyala dan Titik Bakar Aspal Modifikasi

\begin{tabular}{cccc}
\hline No. & Kadar & $\begin{array}{c}\text { Suhu Nyala } \\
\left({ }^{\circ} \mathrm{C}\right)\end{array}$ & $\begin{array}{c}\text { Suhu Bakar } \\
\left({ }^{\circ} \mathrm{C}\right)\end{array}$ \\
\hline 1. & $0 \%$ & 288,8 & 297,7 \\
2. & $1 \%$ & 275,1 & 287,5 \\
3. & $2 \%$ & 268,1 & 280,2 \\
4. & $3 \%$ & 258,3 & 271,2 \\
5. & $4 \%$ & 245,3 & 258,0 \\
6. & $5 \%$ & 235,1 & 252,8 \\
7. & $6 \%$ & 227,8 & 233,3 \\
8. & $7 \%$ & 220,6 & 227,4 \\
9. & $8 \%$ & 210,8 & 223,5 \\
\hline
\end{tabular}

Hasil pengujian yang terdapat pada Tabel 6 menunjukkan bahwa penambahan kadar plastik LDPE yang semakin besar akan menurunkan titik nyala dan titik bakar aspal modifikasi, karena sifat plastik tersebut mudah terbakar pada temperatur yang tidak terlalu tinggi. Kadar penambahan plastik LDPE maksimal untuk aspal modifikasi pada pengujian titik nyala dan titik bakar yang memenuhi persyaratan Bina Marga adalah 5\%. Kadar plastik $6 \%, 7 \%$, dan $8 \%$ tidak menghasilkan aspal modifikasi yang memenuhi persyaratan, karena titik nyala aspal modifikasi yang dihasilkan kurang dari $232^{\circ} \mathrm{C}$.

\section{Pengujian Viskositas}

Pengujian viskositas dilakukan dengan cara mencampur aspal dengan plastik LDPE, kemudian dimasukkan ke dalam alat Saybolt Viscometer untuk menentukan tingkat kekentalan aspal modifikasi yang dihasilkan. Persyaratan viskositas kinematis untuk aspal modifikasi dengan plastik yang telah ditetapkan oleh Bina Marga adalah maksimum 3.000 cSt pada temperatur $135^{\circ} \mathrm{C}$. Hasil pengujian viskositas aspal modifikasi dengan plastik LDPE dapat dilihat pada Tabel 7.

Hasil pengujian menunjukkan bahwa penambahan kadar plastik LDPE berbanding lurus dengan tingkat kekentalan aspal. Semakin besar penambahan plastik LDPE akan semakin besar pula tingkat kekentalan aspal modifikasi plastik yang dihasilkan. Hal 
tersebut karena plastik LDPE memiliki sifat tahan terhadap temperatur tinggi sehingga membuat plastik LDPE sulit dicairkan dan memiliki kekentalan yang tinggi. Kadar plastik yang memenuhi persyaratan spesifikasi aspal modifikasi polimer menurut Bina Marga adalah antara $0 \%$ sampai $6 \%$ karena nilai viskositas kinematisnya kurang dari $3.000 \mathrm{cSt}$.

Tabel 7 Hasil Pengujian Viskositas Aspal Modifikasi

\begin{tabular}{ccc}
\hline No. & Kadar Plastik & $\begin{array}{c}\text { Viskositas Kinematis Temperatur } \\
135^{\circ} \mathrm{C}(\mathrm{cSt})\end{array}$ \\
\hline 1. & $0 \%$ & 1327,36 \\
2. & $1 \%$ & 1639,36 \\
3. & $2 \%$ & 1950,56 \\
4. & $3 \%$ & 2235,33 \\
5. & $4 \%$ & 2573,49 \\
6. & $5 \%$ & 2768,88 \\
7. & $6 \%$ & 2974,89 \\
8. & $7 \%$ & 3264,29 \\
9. & $8 \%$ & 3518,52 \\
\hline
\end{tabular}

Berdasarkan hasil pengujian yang diperoleh, kadar plastik yang memenuhi persyaratan Bina Marga untuk pengujian penetrasi adalah 0\% sampai 5\%, kadar plastik untuk pengujian berat jenis adalah $0 \%$ sampai $8 \%$, kadar plastik untuk pengujian daktilitas adalah $0 \%$ sampai $6 \%$, kadar plastik untuk pengujian titik lembek adalah $0 \%$ sampai $8 \%$, kadar plastik untuk pengujian titik nyala dan titik bakar adalah 5\%, dan kadar plastik untuk pengujian viskositas adalah anntara $0 \%$ sampai $6 \%$. Dengan demikian kadar plastik LDPE maksimal yang dapat dicampurkan ke aspal untuk membuat aspal modifikasi adalah 5\%. Hasil analisis kadar plastik LDPE maksimal yang memenuhi persyaratan Bina Marga dapat dilihat pada Tabel 8 .

Tabel 8 Kadar Plastik LDPE Maksimal yang Memenuhi Persyaratan

\begin{tabular}{|c|c|c|c|c|c|c|c|c|c|c|c|}
\hline \multirow{2}{*}{ No. } & \multirow{2}{*}{ Pengujian } & \multirow{2}{*}{$\begin{array}{l}\text { Persyaratan } \\
\text { Bina Marga }\end{array}$} & \multicolumn{9}{|c|}{ Kadar Plastik } \\
\hline & & & $0 \%$ & $1 \%$ & $2 \%$ & $3 \%$ & $4 \%$ & $5 \%$ & $6 \%$ & $7 \%$ & $8 \%$ \\
\hline 1. & Berat jenis & $\geq 1$ & & & & & & & & & \\
\hline 2. & Daktilitias & $\geq 100$ & & & & & & & & & \\
\hline 3. & Penetrasi & $\geq 40$ & & & & & & & & & \\
\hline 4. & Titik lembek & $\geq 54$ & & & & & & & & & \\
\hline 5. & Titik nyala & $\geq 232^{\circ} \mathrm{C}$ & & & & & & & & & \\
\hline 6. & Viskositas & $\begin{array}{l}\leq 3000 \text { pada } \\
\text { temperatur } \\
135^{\circ} \mathrm{C}\end{array}$ & & & & & & & & & \\
\hline
\end{tabular}

\section{KESIMPULAN}

Berdasarkan hasil analisis dan pembahasan yang telah dilakukan, terdapat beberapa temuan yang diperoleh, yaitu:

1) Kadar penambahan plastik LDPE maksimal yang memenuhi persyaratan untuk aspal modifikasi adalah 5\%. Hal tersebut karena hasil-hasil pengujian penetrasi, pengujian 
berat jenis, pengujian daktilitas, pengujian titik lembek, pengujian titik nyala dan titik bakar, serta pengujian viskositas untuk aspal dengan kadar plastik antara $0 \%$ sampai 5\%, memenuhi persyaratan spesifikasi umum Bina Marga 2010.

2) Pengujian yang dilakukan hanya sampai penambahan plastik dengan kadar $8 \%$, karena temperatur pencampuran aspal modifikasi sangat tinggi dan mendekati titik nyala aspal penetrasi 60/70, yaitu sekitar $190^{\circ} \mathrm{C}$.

3) Aspal modifikasi dengan plastik LDPE menurunkan nilai penetrasi aspal, berat jenis aspal, tingkat keplastisan aspal, titik nyala dan titik bakar aspal, viskositas aspal, serta meningkatkan titik lembek aspal. Hal tersebut membuat aspal semakin keras dan tahan terhadap temperatur tinggi sehingga tidak mudah untuk berubah bentuk (deformasi).

4) Plastik limbah LDPE saat dicampurkan langsung ke aspal menghasilkan campuran yang tidak homogen sempurna (menggumpal). Hal tersebut karena titik leleh plastik LDPE lebih tinggi daripada titik leleh aspal. Untuk menghasilkan campuran yang homogen sempurna diperlukan alat pengaduk berupa mixer berkekuatan tinggi.

\section{DAFTAR PUSTAKA}

Bina Marga. 2010. Spesifikasi Umum Bidang Jalan dan Jembatan. Jakarta: Direktorat Jendral Bina Marga.

Rahmawati, A. 2015. Pengaruh Penggunaan Plastik Polyethylene (PE) dan High Density Polyethylene (HDPE) pada Campuran Lataston-WC terhadap Karakteristik Marshall. Jurnal Ilmiah Semesta Teknika, 18 (2): 147-159.

Rahmawati, A. dan Rizana, R. 2013. Pengaruh Penggunaan Limbah Plastik Polipropilena Sebagai Pengganti Agregat pada Campuran Laston terhadap Karakteristik Marshall (105M). Konferensi Nasional Teknik Sipil Ke-7. Universitas Sebelas Maret, Surakarta.

Sistra, M.D., Setyawan, A., dan Sarwono, D. 2016. Analisis Karakteristik Modifikasi Aspal Penetrasi 60/70 dengan Ethylene Vinyl Acetate (EVA). e-Jurnal Matriks Teknik Sipil, 4 (1): 120-127.

Sunarya. 2016. Penentuan Rute Pengambilan Sampah Menggunakan Metode Nearest Neighbor di PD Kebersihan Kota Bandung untuk Kapasitas Kendaraan 10 M3 dengan Daerah Pelayanan Bandung Selatan dan Bandung Timur. Skripsi tidak diterbitkan. Bandung: Universitas Pasundan.

Syahputri, R.T. 2014. Penentuan Karakteristik Aspal Sintetis dari Campuran Limbah Plastik Hdpe dan Karet Ban Bekas dengan Pelarut Oli Bekas. Skripsi tidak diterbitkan. Palembang: Universitas Sriwijaya.

Wantoro, W., Kusumaningrum, D., Setiadji, B.H., dan Kushardjoko, W. 2013. Pengaruh Penambahan Plastik Bekas Tipe Low Density Polyethylene (LDPE) terhadap Kinerja Campuran Beraspal. Jurnal Karya Teknik Sipil, 2 (4): 366-381. 